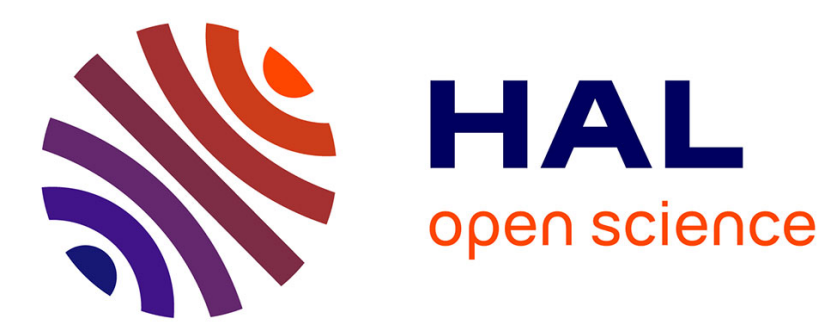

\title{
Lean Thinking in the Digital Era
}

Elisa Negri, Daryl Powell, Sergio Terzi, Laura Cattaneo, Monica Rossi

\section{To cite this version:}

Elisa Negri, Daryl Powell, Sergio Terzi, Laura Cattaneo, Monica Rossi. Lean Thinking in the Digital Era. 14th IFIP International Conference on Product Lifecycle Management (PLM), Jul 2017, Seville, Spain. pp.371-381, 10.1007/978-3-319-72905-3_33. hal-01764207

\section{HAL Id: hal-01764207 https://hal.inria.fr/hal-01764207}

Submitted on 11 Apr 2018

HAL is a multi-disciplinary open access archive for the deposit and dissemination of scientific research documents, whether they are published or not. The documents may come from teaching and research institutions in France or abroad, or from public or private research centers.
L'archive ouverte pluridisciplinaire HAL, est destinée au dépôt et à la diffusion de documents scientifiques de niveau recherche, publiés ou non, émanant des établissements d'enseignement et de recherche français ou étrangers, des laboratoires publics ou privés. 


\title{
Lean Thinking in the Digital Era
}

\author{
Laura Cattaneo ${ }^{1}$, Monica Rossi ${ }^{1}$, Elisa Negri ${ }^{1}$, Daryl Powell ${ }^{2}$, Sergio Terzi ${ }^{1}$ \\ ${ }^{1}$ Politecnico di Milano, Department of Management, Economics and Industrial Engineering \\ Piazza Leonardo da Vinci, 20133, Milano, Italy \\ \{laura1.cattaneo,monica.rossi, elisa.negri, sergio.terzi\}@polimi.it \\ ${ }^{2}$ Kongsberg Maritime AS, Horten, Norway; Norwegian University of Science and Technol- \\ ogy, Department of Economics and Technology Management, Trondheim, Norway \\ daryl.j.powell@ntnu.no
}

\begin{abstract}
The Industry 4.0 concept represents a paradigm shift where physical objects are seamlessly integrated into information networks. This promises to enable a more effective infrastructure in which the design, development, manufacturing and support activities that represent the key parts of a product's life cycle are closely integrated through the presence of real-time information and big data, arising from sensors, Cyber Physical Systems, Internet of Things and social networks. The challenge is to understand how to use this extensive information in order to enhance product value and to improve industrial productivity. Since information must be displayable, reusable and available in real-time, the fourth industrial revolution is already well-aligned with lean thinking, which promotes information visualization, including the just-in-time delivery of materials and information, as well as the zero defects ideal to quality management. Moreover, Lean thinking forces the development of human resource capabilities, through the adoption of scientific problem solving and continuous improvement approaches. These approaches must continue to underpin the leadership and employee development activities required in light of Industry 4.0. Through a systematic literature review, this paper describes the current state of the art in order to understand how lean thinking should be implemented in the context of the smart factory, and provides an initial contribution to the emerging debate around the roles of "Lean Thinking in the Digital Era".
\end{abstract}

Keywords: lean thinking, digital era, Industry 4.0, smart manufacturing, productivity, lean 4.0. 


\section{Introduction}

Today, consciously or not, industries have to compete in a data-driven world, where the volume of available data is continuously increasing thanks to the development of technologies such as digital platforms, sensors, mobile phones, etc. [1]. In this context, the range of applications and opportunities has grown exponentially, provided that industries are able to capture data intrinsic value. Data come from different sources, have different formats, affect different parts of the value chain and are essential to learning and knowledge-creation. The big challenge is ensuring that users get the most from the data, i.e. using it to increase the probability of making the right decisions, in the right context and for the right reasons. Indeed most companies are capturing only a fraction of the potential value of data and analytics and the biggest barriers companies face in extracting value from data are organizational, since companies struggle daily to incorporate data-driven insights into day-to-day business processes [1]. This problem statement presents a series of questions that need to be answered by carrying out research in this field: Who is in charge to manage data and data sources within companies? What kind of analysis and models should be implemented to learn from the information contained in Big Data? Which manufacturing system may ideally include data-driven insights into day-to-day business processes? How does the concept of productivity change in the digital context?

Lean thinking is still the most powerful philosophy to optimize operations throughout the entire manufacturing enterprise, focusing on continuous process improvements driven by customer demand, on rooting out production inefficiencies and engaging all the employees in the application of lean principles and actions like value creation, waste elimination, respect for people and continuous improvement [2] [3]. Specific attention should be paid to product and process development where lean thinking promotes the creation, use and reuse of knowledge for learning purposes [4]. Developing products and manufacturing processes is much more effective when based on formal and properly managed knowledge that prevents the company from taking wrong decisions and leads towards a better definition of customer value [5]. For the sake of knowledge formalization and learning, the access, interpretation and use of data will become increasingly more paramount for competitive advantage during the fourth industrial revolution. And the lean principles of doing what is needed, how it is needed, when it is needed [6] seem to translate here into enabling a system to provide the information that is needed, when it is needed, where it is needed, and in the right format (how it is needed). This is certainly not an easy task in such a chaotic "big data ocean". Hence, it would seem natural to find a way to understand how lean thinking can serve as enabler of Industry 4.0 and the digital era.

The paper is organized as follows: in Section 2 the research statement is outlined, explaining the rationale of the research and introducing the framework of Industry 4.0 and smart manufacturing, by exploring what kinds of information are 
available thanks to sensors, Internet of Things (IoT), social networks, IT platforms and so on. In Section 3 we present the state of the art regarding lean thinking in the digital era. Finally, a critical analysis on the findings is discussed in Section 4, with the objective of creating a common understating on existing studies, delineating open issues and research directions in the field of "Lean in the Digital Era".

\section{Research Design}

Lean thinking in the digital era drives the rational of this research, which starts with this initial framing paper and will continue with more in depth reasoning and fact-based findings in due course. The overall objective of the study will be to understand how data and analytics tools could underpin lean thinking (and vice versa) in order to ultimately deliver customer value centric products, by fulfilling customer requirements and increasing industry productivity. As a first contribution to such a debate, this paper starts the illustration of the current research status on lean thinking and Industry 4.0, through a systematic literature review, in order to provide an overview, synthesis and a critical assessment of previous research, challenge existing knowledge and identify and define novel research problems and research questions [7]. The paper presents the illustration of the existing literature by querying the main academic databases, around the keywords "Industry 4.0", "Smart Manufacturing" and "Lean", [8], as will be illustrate in the Section 3.

\subsection{Industry 4.0 in the data-driven world}

In the recent years, the volume of available data and information has grown exponentially, coming from digital platforms, wireless sensors, social networks and mobile phones. In the meanwhile data storage capacity has increased and its cost is drastically lowered. Computer power opened the way to the development of new and sophisticated algorithms [1]. We are entering a new industrial era, called Industry 4.0. This term has been coined at the 2011 Hannover Fair by Siegfried Dais (Robert Bosch $\mathrm{GmbH}$ ) and Henning Kagermann (Acatech) [9] and it represents a politically established target for the production industry, intending to apply the principles of Cyber-Physical Systems (CPS), internet and future-oriented technologies and smart systems, with enhanced human-machine interaction paradigms [10]-[12]. It is currently being operationalized in different national initiatives, some examples are "Industry 4.0" in Germany, "Industry 2025" in Switzerland, "Smart Manufacturing" in USA, "Industria 4.0" in Italy, "Norge 6.0" in Norway, "Usine du Futur" in France and "High Value Manufacturing" in UK. Thus, its name has not yet been consolidated at an International level. Each of these national initiatives has led to the creation of various entities and programs, to leverage on technologies that allow easy integration of interconnected intelligent "things" inside the shopfloor with the objective to build smart, adaptive and resource effi- 
cient factories which can integrate the business processes and values in the whole supply chain [9]. The technological basis for the Industry 4.0 is the Internet of Things (IoT), first proposed in 1999 by the MIT [13]. In IoT, physical objects (i.e. the "things") are remotely sensed and controlled for a tighter integration between the physical and digital worlds, creating networks of "things" able to autonomously collect and flow data to other objects through the internet thanks to an embedded connectivity at electronic and software level [14]. Thanks to such radical technological developments, IoT is now mature and can be exploited costeffectively at an industrial level within the so-called Industry 4.0. This consists of the use of intelligent manufacturing technologies linked to be able to communicate and deliver copious amounts of sensed data in real-time to allow having better predictability and optimization capabilities with respect to the production plant and higher customization levels in the products [15], [16]. Therefore, Industry 4.0 is anticipated to be one of the keys to facing the turbulent and unpredictable market contexts currently faced by many manufacturing companies, characterized by shorter product lifecycles, frequent introduction of new and customized products, and shorter delivery lead times [17]-[19]. Industries and companies in front of this new challenging context feel that they may take advantages from data and analytics, but some questions arise and some points should be clarified.

\section{Lean Thinking in the Digital Era: Literature Review}

\subsection{Review method}

The paper focuses on the discussion based on the findings retrieved from a systematic literature review of the state of the art of lean thinking in the digital era [8], [20]. We perform the literature review of scientific articles by filtering articles according to the keywords "Industry 4.0", "Smart Manufacturing" and "Lean", which are the basic concepts of our research framework. Since the concept of "Industry 4.0 " is connected to national initiatives with no recognized consolidation at an international level (as mentioned in the previous paragraph), we choose to extend our search to include other related terms, in order to capture documents that do not explicitly belong to the "Industry 4.0" domain but are factually related to parallel initiatives. We know that concepts are not only expressed using specific terms, they are also described and paraphrased. This is of particular importance when looking at emerging phenomena or new research areas, as these are generally still establishing a specific terminology to talk about the research domain in its various aspects [7]. It is worth pointing out that this paper aims at giving an exhaustive systematic literature review around the above mentioned keywords, though the paper is part of an on-going broader literature review, that will include additional keywords, as discussed in the conclusion in Section 4. 
Scientific documents are selected through the most popular scientific works search engine (Scopus, Google Scholar, Web of Science, Science Direct, Wiley Online Library, World Wide Science, Base, Emerald) and we stop the research when repetition of materials reaches a significant value [8].

We perform two different searches, combining "Industry 4.0" AND "Lean", and "Smart Manufacturing" AND "Lean". The terms are searched for in the titles, abstracts and keywords. Among the results, we perform a first selection of scientific documents filtering the language and the subject. In terms of language only English documents are taken into account in this research. Regarding the subject, we select papers belonging to these subject areas: business, management and accounting, computer science, economics, econometrics and finance, engineering, chemical engineering, mathematics, energy and environmental science, earth and planetary science, decision science, neuroscience and social science. By applying these filters, we deal with a total of 458 documents (including articles, proceeding papers and master theses). In this number, some articles appear more times as they appear in different search engines. After the first selection of documents, we perform three stages of filtering, following [20]: screen titles, read abstracts and screen full texts. After filtering, irrelevant papers are rejected, and we deal with a total of 42 documents. Table 1 illustrates the number of documents found in each search engine, for both the keywords combination.

Table 1. Documents' sample

\begin{tabular}{lcc}
\hline & Industry 4.0 AND Lean & $\begin{array}{c}\text { Smart Manufacturing AND } \\
\text { Lean }\end{array}$ \\
\hline Scopus & 19 & 54 \\
Google Scholar & 18 & 19 \\
Web of Science & 31 & 38 \\
Science Direct & 52 & 7 \\
Wiley Online Library & 17 & 7 \\
World Wide Science & 26 & 35 \\
Base & 18 & 74 \\
Emerald & 34 & 9 \\
Total (458 documents) & 215 & 243 \\
\hline
\end{tabular}

\subsection{Descriptive analysis}

The search and filtering selection process results in 42 scientific documents. We find 24 proceeding papers, 14 Journal articles, 2 book chapters and 2 Master theses. Among all the documents, 21 documents appear as result of different databases. The most repeatedly found document is [21], that appears as result in five different databases (Scopus, Web of Science, Science Direct, World Wide Science, Base). 
In Figure 1 we illustrate the distribution of the 42 papers over time. Since we do not use the publication year as a filter, the oldest document we find has been published in 2010, [22]. We can observe that after 2012 there is a significant increase in publications: this is aligned with the introduction of the Industry 4.0 concept [9].

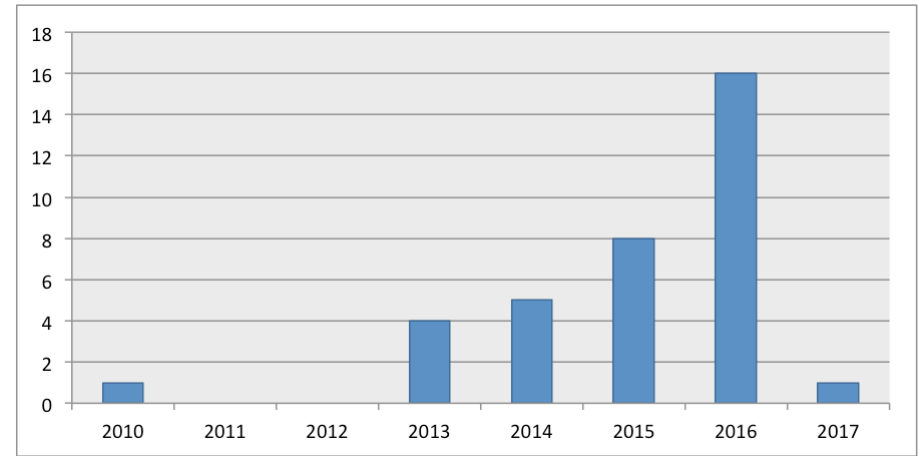

Fig. 1. Distribution of papers over time.

\subsection{Information extraction}

Analysing the documents identified with the research methodology described in the previous paragraph, we perform an initial analysis to delineate the state of the art of the defined research framework, to highlight if and how lean thinking and Industry 4.0/smart manufacturing are connected, to identify which arguments are mainly investigated and to point out which gaps exist.

To investigate which topics are discussed by the selected documents, we fix $a$ priori a list of keywords in order to divide documents by arguments. These keywords are relative to specific lean topics (e.g. human resources, value stream, learning, requirements, productivity) and to particular Industry 4.0 aspects (e.g. Cyber Physical Systems, Internet of Things, big data). We search also for other keywords that, basing on our experiences, could be relevant for this research, such as Information and Communication Technology (ICT), Product Lifecycle Management (PLM), business models, data analytics and data scientists [1]. Results are reported in Table 2. Developing our literature analysis, we found that similar keywords have been obtained as results also in [23], where the authors, doing an opposite process, generate representative Industry 4.0 and lean thinking keywords through a text analysis.

Observing the results summarized in Table 2, we see that one third of the selected documents writes about ICT, comprising computerized technologies, such as CAD and CAE systems, that preceded the introduction of the Industry 4.0 and are already seemingly integrated into lean manufacturing environments. This is confirmed by the fact that most of the articles speaking about ICT result from the "Lean" AND "Smart Manufacturing” search. 
Table 2: Lean and digital topics recurrence in publications. Documents that are not directly cited in the text are reported with first author and year.

\begin{tabular}{|c|c|c|c|c|}
\hline Topic & Articles & $\begin{array}{l}\text { Conference } \\
\text { Proceedings }\end{array}$ & Other & Tot \\
\hline ICT & $\begin{array}{l}\text { [22] } \\
\text { [V.G. Smelov, 2014] } \\
\text { [I. Veza, 2016] } \\
\text { [M. S. Amalnik, } \\
\text { 2015] } \\
\text { [R. Mason-Jones, } \\
\text { 2006] }\end{array}$ & $\begin{array}{l}\text { [27][S. Ulonska, 2013] } \\
{[\text { M. Lanz, 2014] }} \\
{[\text { N. Gjeldum, 2016] }} \\
{[\text { E. Rauch, 2016] }} \\
{[\text { S. W. Doh, 2016] }} \\
{[\text { P. Dallasega, 2016] }} \\
{[\text { B. Mrugalska, 2016] }}\end{array}$ & $\begin{array}{l}\text { [D. Ivanov, } \\
\text { 2017] }\end{array}$ & 14 \\
\hline $\begin{array}{l}\text { Human } \\
\text { Resources }\end{array}$ & $\begin{array}{l}{[10][25]} \\
{[P . \text { Edwards, 2016] }} \\
{[\text { S. V Sibatrova, 2016] }}\end{array}$ & $\begin{array}{l}{[24][27]} \\
{[\text { Hanna Theuer, 2013] }} \\
{[\text { I. Giuliano, 2014] }} \\
{[\text { M. Boscoianu, 2015] }} \\
\text { [D. Kolberg, 2015] } \\
\text { [S. W. Doh, 2016] } \\
\text { [R. J. Eleftheriadis, 2016] }\end{array}$ & $\begin{array}{l}{[\text { M. T. M. }} \\
\text { Ramadan, } \\
\text { 2016] }\end{array}$ & 13 \\
\hline Value & $\begin{array}{l}{[25]} \\
\text { [V. G. Smelov, 2014] } \\
{[\text { S. E. Chick, 2014] }} \\
{[\text { I. Veza, 2016]] }} \\
\text { [S. V Sibatrova, 2016] }\end{array}$ & $\begin{array}{l}\text { [I. Giuliano, 2014] } \\
\text { [G. Ringen, 2014] } \\
{[\text { U. Hurt, 2015] }} \\
{[\text { E. Rauch, 2016] }} \\
\text { [S. W. Doh, 2016] } \\
{[\text { B. Wang, 2016] }}\end{array}$ & $\begin{array}{l}{[\mathrm{M} . \text { T. M. }} \\
\text { Ramadan, } \\
\text { 2016] }\end{array}$ & 12 \\
\hline Requirements & $\begin{array}{l}{[11][25][26]} \\
{[\text { T. Chen, 2017] }}\end{array}$ & $\begin{array}{l}{[24][\text { S. Ulonska, 2013] }} \\
{[\text { A. Ojamaa, 2013] }} \\
{[\text { R. J. Eleftheriadis, }} \\
\text { 2016][ J. Um, 2015] } \\
{[\text { E. Rauch, 2016] }}\end{array}$ & $\begin{array}{l}\text { [Hanna } \\
\text { Theuer, } \\
\text { 2013] }\end{array}$ & 11 \\
\hline Productivity & $\begin{array}{l}{[10][25]} \\
{[\text { I. Veza, 2016] }} \\
{[\text { T. Chen, 2017] }}\end{array}$ & $\begin{array}{l}{[23][\text { M. Lanz, 2014] }} \\
{[\text { H. Huang, 2015] }} \\
{[\text { S. V Sibatrova, 2016] }}\end{array}$ & $\begin{array}{l}\text { [M. T. M. } \\
\text { Ramadan, } \\
2016] \\
{[O .} \\
\text { Gunaydi, } \\
\text { 2016] } \\
\text { [D. Ivanov, } \\
\text { 2017] }\end{array}$ & 10 \\
\hline $\begin{array}{l}\text { Cyber- } \\
\text { Physical } \\
\text { Systems }\end{array}$ & $\begin{array}{l}{[10][11][26]} \\
{[\text { S. V Sibatrova, 2016] }}\end{array}$ & $\begin{array}{l}{[27][D . \text { Kolberg, 2015] }} \\
{[\text { S. W. Doh, 2016] }} \\
\text { [R. J. Eleftheriadis, } \\
\text { 2016][Z. Stojkic, 2016] }\end{array}$ & & 9 \\
\hline $\begin{array}{l}\text { Internet of } \\
\text { Things }\end{array}$ & $\begin{array}{l}{[10][11][25]} \\
{[\text { S. V Sibatrova, 2016] }}\end{array}$ & [23][M. Lanz, 2014] & & 6 \\
\hline PLM & $\begin{array}{l}\text { [V.G. Smelov, 2014] } \\
\text { [M. S. Amalnik, } \\
\text { 2015] }\end{array}$ & $\begin{array}{l}\text { [27][S. Ulonska, 2013] } \\
{[\text { N. Gjeldum, 2016] }} \\
{[\text { E. Rauch, 2016] }}\end{array}$ & & 6 \\
\hline $\begin{array}{l}\text { Data } \\
\text { Management }\end{array}$ & $\begin{array}{l}\text { [R. Mason-Jones, } \\
\text { 2006] } \\
\text { [S. E. Chick, 2014] }\end{array}$ & $\begin{array}{l}\text { [S. Ulonska, 2013] } \\
\text { [A. Ojamaa, 2013] }\end{array}$ & $\begin{array}{l}\text { [M. T. M. } \\
\text { Ramadan, } \\
\text { 2016] }\end{array}$ & 5 \\
\hline
\end{tabular}




\begin{tabular}{|c|c|c|c|c|}
\hline Learning & & $\begin{array}{l}\text { [21][24][N. Gjeldum, } \\
\text { 2016][S. J. Blochl, 2016] }\end{array}$ & & 4 \\
\hline $\begin{array}{l}\text { Data } \\
\text { Analytics }\end{array}$ & {$[10][25][\mathrm{J} . \mathrm{Um}, 2015]$} & & $\begin{array}{l}{[O .} \\
\text { Gunaydi, } \\
2016]\end{array}$ & 3 \\
\hline Big Data & $\begin{array}{l}{[10]} \\
{[S . \text { V Sibatrova, 2016] }}\end{array}$ & [J. Cao, 2016] & & 3 \\
\hline $\begin{array}{l}\text { Business } \\
\text { Model }\end{array}$ & [V.G.Smelov, 2014] & & & $\mathbf{1}$ \\
\hline 3D Printing & [T. Chen, 2017] & & & $\mathbf{1}$ \\
\hline Data Scientist & & & & $\mathbf{0}$ \\
\hline
\end{tabular}

After ICT keywords, the most recurrent keywords are related to lean thinking: human resources (13 documents), value (12 documents), requirements (11 documents) and productivity (10 documents). Among these topics, biggest attention is given to human resource. As reported in [24], investing in the latest technology alone will not provide the required systems capabilities, but it is crucial to invest in knowledge and people skills. It is interesting to see that none of the human resource related documents explicitly mention data scientists and only two of them discuss data analytics ([10], [25]). In particular [25] discusses a hybrid lean-agile approach in the automotive sector. [10] speaks about "Control and Human Factors", including scenarios as total productive/preventive maintenance, statistical process control and employee involvement. In particular, the authors underline that IoT assists in integration of different value adding processes by combining information and data from different machines. In spite of this, the authors do not clarify which human resource activities must be involved in the analytics processes. Another big challenge that emerges from Table 2 is the definition of value. Companies have to understand what value means for them and how to measure it. In the new data-driven context, they need to understand how data can influence industry productivity and performance and how to quantify this. These concepts are so far scarcely studied, as we see from Table 2 there are few connections between "Value", "Productivity" and the data world, i.e. "Cyber Physical Systems", "Internet of Things" and "Data Management". Among the common results, [10] indirectly writes of productivity, saying that financial benefits could be measured as a reduction or elimination of redundant wastes. [11] underlines that lean manufacturing system's performance can be integrated into CPS control algorithms, suggesting that Just-In-Time was the highest performing system. But the authors conclude their work by pointing out that further studies are needed to analyse the influence on performance variables and to investigate the necessary capital investment to actually implement Industry 4.0 on the shop floor.

Few papers, among those selected, explicitly talk about "Cyber Physical Systems" (9 documents), "Internet of Things" (6 documents) and "Big data" (3 documents). For example, [24] focus on automated manufacturing, discussing organizational capabilities and tools required to enable transformation into Industry 4.0. 
However, the authors write that the dominant technologies within Industry 4.0 are expected to be I(C)T, electronics and robotics, never talking about data, CPS or IoT. They write that it is important to execute value-creating activities with the correct information input and suggest that the use of prototypes enable rapid learning minimizing mistakes. These prototypes can be produced combining Computeraided solutions and Virtual Reality. [26] describes work on a common, unified communication interface in order to digitise lean production methods and how CPSs have been used to encapsulate and retrofit workstations. Nonetheless in [26] the technological bases of Industry 4.0 (such as Big Data and IoT) are never mentioned. Among the papers talking about data technologies, [10] is particularly interesting, since the authors explicitly state when CPS, IoT and Big Data can be used as solutions for lean principles implementation. Nonetheless, they observe that some researches in Industry 4.0 are purely theory-oriented and not readily adaptable to a real-life application. Also [11] tries to explain the potential advantages that lean could achieve in combination with CPS and IoT, supporting the fact that Industry 4.0 must be integrated into the comprehensive lean theory framework. However, they also state that the Industry 4.0 initiative has a high probability to fail if it is not put into the right context by considering fundamental manufacturing principles. [26] says that there is a need for research to understand how CPSs can be integrated into existing production environments and to realize what processes they can support.

We observe also that there are few links between lean practices, Product Lifecycle Management (PLM) and the digital world, since only 6 documents discuss PLM. It is interesting to notice that, among these articles, no one is directly connecting with IoT and Big Data and only [27] writes about CPS. Furthermore, none of them are concerned with data management and data analytics.

We can conclude that although there is an extant body of literature dealing with lean thinking and the digital era, the fundamental Industry 4.0 technologies, big data and PLM principles are seldom mentioned, suggesting that the research stream is still in its infancy.

\section{Conclusion and future research}

This paper is intended to start a broader discussion on how lean thinking can and should be integrated in the digital era. Since the 1990s, the widespread adoption of lean thinking within and across industries has contributed to a truly lean world [28]. More recently, the digital era allows us to deal with lots of information, arising from sensors, CPS, IoT and social networks. The challenge is to understand how to use these technologies in order to build on the fundamentals of lean thinking and create even more value and to improve industrial productivity. In particular, information must be displayable, reusable and must be provided to the right person, in the right format, at the right moment. Lean thinking has vast 
potential in the digital era since it promotes information visualization, the just-intime delivery and achieving more with less, for example using no more information than is required. Moreover, lean thinking has an impact on human resources (customer involvement, employee involvement, leadership development) and on problem-solving techniques, to manage information in a proper way, knowing what, how, when and why information must be available. Therefore, the integration of digital technologies with lean manufacturing seems reasonable and beneficial. Nonetheless, a number of fundamental issues remain unaddressed. Further research must be carried out to address the following areas:

- To investigate the machine-human interaction and to understand how to integrate new professional functions such as data scientists in the current manufacturing environment [1]. Although software can run algorithms to explore data, there is still a need for human resources to be able to manage different challenges: to understand the context from which the data arises, to interpret the data and sometimes to translate data languages and to choose suitable analyses methods. In "data driven" problems (unsupervised learning), data scientists must be able to extract hidden information from data and use them to better explain or solve situational problems. In "problem driven" situations (supervised learning), data scientists must be able to find a way to extract data from suitable sources and to use them to test hypotheses. In both cases, data scientists must be able to provide the right knowledge, to the right person, in the right moment and with the right language and should be able to speak with other specific industrial resources (business partners, designers, employees, etc.). Automatically this means implementing lean thinking, which aims to provide the right amount of information, to the right person, in the right moment and in a displayable and reusable format.

- To understand how to define the industrial productivity in the context of digitalized lean, and to understand how to measure it.

- To understand when data are useful or even necessary during the product life cycle. In particular IT tools connected with PLM should contribute to collect, manage, share and make available all information of the products (and in principle also services) along the whole life cycle. It should be natural that existing software solutions must be integrated with suitable statistical tools and algorithms able to perform analyses to extract value and re-usable information from different data sources such as sensors, CPS, IoT and social networks.

This literature review is a starting point for a more exhaustive systematic review, where we want to study in depth the connection between lean thinking and digital technologies. We will perform a more comprehensive analysis, completing the keywords research adding other main keywords such as "data", "digital", "big data" and "human". Qualitative analysis should be replaced by a quantitative analysis, following for example what was carried out in [23], with more emphasis on specific aspects such as human skills integration and technology-human interactions, interconnectivity of data and product life cycle management, and the definition of the industrial productivity in a digitalized lean world. 
Further and deeper studies will be conducted to complete the literature review adding some specific industrial cases, in order to observe how industries are changing and enhancing their productivity applying lean digital thinking.

\section{Acknowledgments.}

This work was partly funded by the European Commission through Manutelligence (GA_636951) Project and by the Research Council of Norway through the SmartChain Research Project.

\section{References}

[1] "The Age of Analytics: Competing in a Data-Driven World," Mckinsey Glob. Inst., 2016.

[2] O. Scheel, O. Eitelwein, S. Monaha, and M. Koelbli, "Digital Lean: The Next Operations Frontier," A.T. Kearney, 2015.

[3] J. P. Womack, D. T. Jones, and D. Roos, The Machine That Changed the World, Rawson Ass. New York: Free Press, 1990.

[4] M. Rossi, J. Morgan, and J. Shook, "Lean Product and Process Development," in The Routledge Companion to Lean Management, Routledge., T. H. Netland and D. J. Powell, Eds. 2017.

[5] M. Rossi, L. Cattaneo, J. Le Duigou, S. Fugier-Garrel, S. Terzi, and B. Eynard, "Lean Product Development and the role of PLM," in Product Lifecycle Management for Digital Transformation of Industries, Springer International Publishing, 2016.

[6] J. P. Womack and D. T. Jones, Lean thinking: banish waste and create wealth in your corporation. 1996.

[7] S. K. Boell and D. Cecez-Kecmanovic, "On Being 'Systematic' in Literature Reviews in IS,” J. Inf. Technol., vol. 30, pp. 161-173, 2015.

[8] D. Page, "Systematic Literature Searching and the Bibliographic Database Haystack," Electron. J. Bus. Res. Methods, vol. 6, no. 2, pp. 171-180, 2008.

[9] N. Jazdi, "Cyber Physical Systems in the Context of Industry 4.0," in Automation, Quality and Testing, Robotics, 2014 IEEE International Conference on, 2014, pp. 1-4.

[10] A. Sanders, C. Elangeswaran, and J. Wulfsberg, "Industry 4.0 implies lean manufacturing: Research activities in industry 4.0 function as enablers for lean manufacturing," J. Ind. Eng. Manag., vol. 9, no. 3, pp. 811-833, 2016.

[11] B. G. Rüttimann and M. T. Stöckli, "Lean and Industry 4.0-Twins, Partners, or Contenders? A Due Clarification Regarding the Supposed Clash of Two Production Systems," J. Serv. Sci. Manag., vol. 9, no. 6, pp. 485-500, 2016.

[12] M. Garetti, L. Fumagalli, and E. Negri, "Role of Ontologies for CPS Implementation in Manufacturing," MPER - Manag. Prod.Eng. Rev., vol. 6, no. 4, pp. 26-32, 2015. 
[13] K. Ashton, “That 'Internet of Things' Thing," RFiD J., vol. 22, no. 7, pp. 97-114, 2009.

[14] S. Sarma, D. L. Brock, and K. Ashton, "The Networked Physical World," Auto-ID Cent. White Pap. MIT-AUTOID-WH-001, pp. 1-16, 2000.

[15] J. Davis, T. Edgar, J. Porter, J. Bernaden, and M. Sarli, "Smart manufacturing , manufacturing intelligence and demand-dynamic performance," Comput. Chem. Eng., vol. 47, pp. 145-156, 2012.

[16] E. Negri, L. Fumagalli, M. Garetti, and L. Tanca, "Requirements and languages for the semantic representation of manufacturing systems," Comput. Ind., vol. 81, pp. 55-66, 2016.

[17] J. Meredith and U. Akinc, "Characterizing and structuring a new make-toforecast production strategy," J. Oper. Manag., vol. 25, pp. 623-642, 2007.

[18] F. Salvador and C. Forza, "Configuring products to address the customization-responsiveness squeeze: A survey of management issues and opportunities," Int. J. Prod. Econ., vol. 91, pp. 273-291, 2004.

[19] S. J. Hu, "Evolving Paradigms of Manufacturing: From Mass Production to Mass Customization and Personalization," in Forty Sixth CIRP Conference on Manufacturing Systems, 2013, vol. 7, pp. 3-8.

[20] T. M. Ming, M. A. Jabar, F. Sidi, and K. T. Wei, "A systematic literature review of computer ethics issue," J. Theor. Appl. Inf. Technol., vol. 78, no. 3, pp. 360-372, 2015.

[21] J. V. Diez, J. Ordieres-Mere, and G. Nuber, "The hoshin kanri tree. Crossplant lean shopfloor management," in 5th Conference on Learning Factories, 2015, vol. 32, pp. 150-155.

[22] A. Lavrin and M. Zelko, "Moving toward the digital factory in raw material resources area," Acta Montan. Slovaca, vol. 15, no. 3, pp. 225$231,2010$.

[23] F. Martinez, P. Jirsak, and M. Lorenc, "Industry 4.0. The End Lean Management?," in The 10th International Days of Statistics and Economics, 2016, pp. 1189-1197.

[24] E. L. Synnes and T. Welo, "Enhancing Integrative Capabilities through Lean Product and Process Development," in 6th CIRP Conference on Learning Factories Enhancing, 2016, vol. 54, pp. 221-226.

[25] S. A. M. Elmoselhy, "Hybrid lean-agile manufacturing system technical facet, in automotive sector," J. Manuf. Syst., vol. 32, pp. 598-619, 2013.

[26] D. Kolberg, J. Knobloch, and D. Zühlke, "Towards a lean automation interface for workstations," Int.J. Prod.Res., pp. 1-12, 2016.

[27] R. J. Eleftheriadis and O. Myklebust, "A Quality Pathway to Digitalization in Manufacturing thru Zero Defect Manufacturing Practices," Proc. 6th Int. Work. Adv. Manuf. Autom., no. January, 2016.

[28] T. H. Netland and D. J. Powell, "A Lean World," in The Rout. Comp. to Lean Management, Routledge., T. H. Netland and D. J. Powell, Eds. 2017. 